\title{
PENYULUHAN HUKUM POLIGAMI DAN NIKAH SIRI MENURUT UNDANG-UNDANG PERKAWINAN
}

\author{
Syarifah Lisa Andriati ${ }^{1}$ \\ Tri Murti Lubis ${ }^{2}$ \\ ${ }^{1,2}$ Fakultas Hukum Universitas Sumatera Utara \\ syarifah_lisa_andriati@usu.ac.id \\ trimurti@usu.ac.id
}

\begin{abstract}
Abstrak
Poligami sering kurang dipahami sehingga mendapatkan tanggapan yang kurang menyenangkan dari khalayak. Meskipun demikian, disepakati bukan ajarannya yang harus disalahkan tapi lebih kepada praktik yang tidak sesuai tapi lebih sering didasarkan untuk pemenuhan nafsu. Padahal di sisi lain, poligami dapat menjadi solusi sosial apabila dilakukan secara benar. Selain itu terdapat juga kriminalisasi dari poligami dan nikah siri.Masalah nikah siri juga ramai dibicarakan di berbagai media cetak maupun elektronik. Terdapat berbagai pandangan terhadap nikah siri terutama yang dilakukan tanpa adanya wali si perempuan. Dalam hal ini timbul berbagai pandangan. Penyuluhan hukum Poligami dan nikah siri yang dilakukan untuk memberikan pemahaman kepada masyarakat tentang hukum poligami dan nikah siri menurut undang-undang perkawinan. Dari hasil evaluasi, kegiatan pelatihan ini dapat dikatakan cukup berhasil. Dari pertanyaan yang diajukan peserta tergambar peningkatan pemahaman peserta terhadap hukum tentang poligami dan nikah siri dan diharapkan dapat segera terbentuk kelompok binaan yang dapat membantu masyarakat dalam menjawab berbagai persoalan yang berkaitan dengan poligami dan nikah siri di lingkungan masyarakat tersebut.
\end{abstract}

Kata Kunci: Poligami, nikah siri, hukum perkawinan

\section{PENDAHULUAN}

Kelurahan Gedung Johor yang terdapat di Kecamatan Medan Johor mempunyai luas wilayah $315 \mathrm{Ha}$ dan jumlah kepala keluarga 6.157 dengan jumlah penduduk Laki-laki berjumlah 14.826 orang dan Perempuan berjumlah 14.562 orang. Total Jumlah penduduk 29.388 orang.

Kecamatan Medan Sunggal dihuni oleh 112.918 orang penduduk dimana penduduk terbanyak berada di Kelurahan Tanjung Rejo yakni sebanyak 31.038 orang. Kecamatan Medan Sunggal berbatasan langsung dengan kecamatan Medan Helvetia disebelah barat dan Kecamatan Medan Baru dan Medan Petisah di sebelah Timur.

Hukum keluarga diartikan sebagai keseluruhan ketentuan mengenai hubungan hukum yang bersangkutan dengan keluarga sedarah

dan keluarga karena perkawinan (perkawinan, kekuasaan orang tua, perwalian, pengampuan, keadaan tidak hadir). Satu bagian penting di dalam hukum keluarga adalah hukum perkawinan.

Hukum perkawinan tidak lain merupakan inti dari hukum keluarga, sehingga semua orang yang telah memenuhi persyaratan yuridis untuk membentuk keluarga yang bahagia, kekal dan berdasarkan Ketuhanan Yang Maha Esa harus mengikuti norma-norma hukum yang terdapat dalam undang-undang tersebut. Dengan perkataan lain, UndangUndang Nomor 1 tahun 1974 dapat dikatakan sebagai suatu contoh hukum nasional yang bertujuan untuk melahirkan unifikasi hukum dalam bidang hukum keluarga.

Diciptakannya Undang-Undang Nomor 1 Tahun 1974 merupakan suatu upaya yuridis untuk mengadakan perubahan dan pembaharuan terhadap pola-pola perkawinan dalam masyarakat yang banyak menimbulkan dampak negatif. Dari perkawinan yang semula banyak dilakukan dengan bebas dan 
seenaknya menjadi perkawinan yang dilakukan dengan syarat-syarat formal. Dari perkawinan yang begitu mudah diputuskan dengan perceraian menjadi suatu perkawinan yang benar-benar membawa kebahagiaan yang kekal berdasarkan Ketuhanan Yang Maha Esa.

Fenomena poligami semakin marak akhir-akhir ini, terutama karena dipertontonkan secara vulgar oleh para tokoh panutan di kalangan birokrasi, politisi, seniman, dan bahkan agamawan. Poligami adalah masalah yang sering diperhatikan di Indonesia, salah satu negara yang memperbolehkan poligami dengan syarat tertentu. Poligami memang termasuk ajaran agama Islam, agama yang dipeluk oleh sebagian besar penduduk Indonesia.

Di masyarakat terutama kalangan Ibu-Ibu ketika mendengar kata "Poligami" muncul berbagai stigma negatif. Hal ini dapat dimaklumi karena bagi laki-laki mungkin ringan bicaranya, akan tetapi bagi wanita hal ini merupakan masalah yang sangat sensitif. Banyak sekali Ibu-ibu yang khawatir sekali dengan Poligami karena khawatir hal itu akan menimpa dirinya.

Banyak sekali perempuan yang tidak siap mendengar kata poligami karena langsung berpandangan buruk bahkan mencaci maki orang yang melakukan Poligami. Orang yang tadinya panutan setelah melakukan poligami dianggap tidak pantas lagi menjadi panutan di masyarakat. Poligami sering dianggap sebagai sesuatu yang tidak benar, dzalim, sehingga pelakunya sering menjadi cemoohan dan contoh yang buruk.

Poligami sering kurang dipahami sehingga mendapatkan tanggapan yang kurang menyenangkan dari khalayak. Meskipun demikian, disepakati bukan ajarannya yang harus disalahkan tapi lebih kepada praktik yang tidak sesuai tapi lebih sering didasarkan untuk pemenuhan nafsu. Padahal di sisi lain, poligami dapat menjadi solusi sosial apabila dilakukan secara benar. Selain itu terdapat juga kriminalisasi dari poligami dan nikah siri.

Akibat stigma negatif tersebut para suami yang hendak berpoligami cenderung untuk menyembunyikan perkawinan untuk kedua kalinya apabila tidak ada izin istri pertama sehingga terjadilah Nikah Siri. Persoalan Nikah Siri ini dapat merugikan bagi perempuan dan anak yang dilahirkan karena perkawinan yang tidak tercatat secara administrasi sehingga tidak diakui oleh negara.

Berkaitan dengan pencatatan perkawinan, ditemukan fakta adanya ketidakpatuhan yang dilakukan oleh masyarakat di beberapa daerah yang melakukan pernikahan atau perkawinan dengan tidak melakukan pencatatan sebagaimana telah ditentukan dalam UU No. 1/1974.Hal ini dapat menimbulkan berbagai akibat pada kehidupan perkawinan seseorang yang tidak sesuai dengan ketentuan-ketentuan yang berlaku atau dapat disebut pula perkawinan yang tidak taat hukum.Pernikahan seperti ini biasanya disebut pernikahan siri. Masalah nikah siri juga ramai dibicarakan di berbagai media cetak maupun elektronik. Terdapat berbagai pandangan terhadap nikah siri terutama yang dilakukan tanpa adanya wali si perempuan. Dalam hal ini timbul berbagai pandangan.

Realitas perkawinan siri adalah seperti fenomena gunung es, banyak terjadi di masyarakat, tetapi hanya kecil muncul ke permukaan dan umumnya dipublikasikan ketika pelaku pejabat publik atau tokoh masyarakat. Dampak negatif dari perkawinan siri dialami oleh banyak wanita (isteri) dan anak-anak jika suaminya tidak bertanggung jawab.

\section{Undang-Undang Nomor 1 Tahun} 1974 yang memberikan rumusan Perkawinan sebagai berikut :

Perkawinan ialah ikatan lahir batin antara seorang pria dengan seorang wanita sebagai suami istri dengan tujuan untuk membentuk keluarga (rumah tangga) yang bahagia dan kekal berdasarkan Ketuhanan Yang Maha Esa.

Perlu mendapat perhatian khusus adalah asas monogami relatif yang dianut oleh Undang-Undang Nomor 1 Tahun 1974 karena persoalan ini banyak terjadi dalam masyarakat dan selalu mendapat kritik dari golongan kaum wanita disebabkan suaminya beristrikan lebih dari 1 (satu) orang alias berpoligami, baik yang 
dilakukan secara terang-terangan maupun tersembunyi.

Menurut Catatan Komnas HAM tahun 2016, salah satu faktor penyebab terjadinya kekerasan terhadap perempuan adalah menurut PP No.9 tahun 1975 tentang pelaksanaan UU No.1 tahun 1974 tentang perkawinan yang menjadi salah satu dasar kategorisasi Badan Pengadilan Agama khususnya dalam konteks perceraian, yakni: tidak adanya lagi keharmonisan, tidak adanya tanggungjawab, dan faktor ekonomi. Selain itu juga disebabkan oleh gangguan pihak ketiga, krisis ahlak, poligami tidak sehat, cemburu, kawin paksa,kekejaman jasmani, kekejaman mental, kawin dibawah umur, faktor politis, cacat biologis, salah satu pihak dihukum dan lain-lain. Dalam perspektif Komnas Perempuan, kategorisasi di atas seperti kategori poligami tidak sehat, krisis ahlak, belum sejalan dengan prinsip HAM perempuan, misalnya kategori poligami tidak sehat, bila ditelaah dari perspektif korban, pengaduan poligami yang dilaporkan ke Komnas Perempuan adalah salah satu bentuk kekerasan terhadap perempuan.

Adapun yang menjadi mitra dalam pengabdian ini adalah kalangan Ibu-Ibu Perwiritan di Kelurahan Gedung Johor dan Kelurahan Medan Sunggal yang sering khawatir apabila mendengar istilah poligami. Hal ini dikarenakan kurang pemahaman hukum terhadap poligami itu sendiri karena dalam undang-undang diberikan suatu batasan tertentu apabila seorang suami ingin menikah lebih dari satu. Dan banyaknya masyarakat yang tidak paham tentang pernikahan siri sehingga banyak yang pihak yang dirugikan dengan adanya pernikahan siri terutama terhadap perempun dan anak. Sebagaimana dijelaskan adapun permasalahan yang akan di bahas antara lain: Bagaimana ketentuan Poligami dan Nikah Siri Menurut Hukum Perkawinan di Indonesia? Dan Bagaimana solusi hukum terhadap persoalan masyarakat yang berkaitan dengan poligami dan nikah siri Perwiritan Kelurahan Gedung Johor dan di Perwiritan Kelurahan Tanjung Rejo?

\section{METODE}

Seperti telah disebutkan pada bab Pendahuluan bahwa poligami dan nikah siri menjadi persoalan yang mengkhawatirkan terutama dikalangan Ibu-Ibu rumah Tangga. Kurangnya pemahaman hukum mengenai persoalan poligami dan nikah siri mengakibatkan keresahan di masyarakat. Dalam Undangundang Perkawinan yaitu UU No.1 Tahun 1974 tentang Perkawinan dan peraturan pelaksananya serta Kompilasi Hukum Islam telah mengatur bagaimana perkawinan yang sah menurut ketentuan hukum agama dan hukum negara.

Adapun tahapan-tahapan kegiatan yang akan dilakukan adalah

1) melakukan koordinasi terlebih dahulu pada pemerintahan setempat untuk mensosialisasikan rencana kegiatan penyuluhan hukum. Tujuan sosialisasi ini adalah untuk mengenalkan program kegiatan yang akan dilakukan.

2) Melakukan sosialisasi program kepada Ibu-Ibu perwiritan sekaligus menyebarkan angket. Tujuannya untuk mengukur tingkat pemahaman masyarakat terhadap masalah poligami dan nikah siri.

3) Dalam kegiatan ini akan melibatkan 3 mahasiswa sehingga mahasiswa akan membantu pelaksanaan kegiatan pengabdian untuk masyarakat ini.

4) Menyiapkan materi penyuluhan dan buku saku

5) Melaksanakan kegiatan penyuluhan hukum di dua keluarahan yaitu kelurahan Gedung Johor dan kelurahan Tanjung Rejo.

6) Melakukan evaluasi dengan menyebarkan angket untuk melihat tingkat pemahaman peserta setelah penyuluhan dilakukan.

\section{HASIL DAN PEMBAHASAN}

Pengabdian pada $\mathrm{m}$ asyarakat dengan dana BPPTN USU tahun 2017 dilakukan pada dua perwiritan yakni Perwiritan Nurul Iman yang terletak di Jalan Eka Suka Kelurahan Gedung Johor Kecamatan Medan Johor dan Perwiritan Masjid Al-Hikmah yang terletak di Jalan Kiwi Kelurahan Tanjung Rejo Kecamatan 
Medan Sunggal. Sebelum penyuluhan hukum dilakukan di dua perwiritan tersebut dipersiapkan terlebih dahulu Buku Saku yang akan di bagikan kepada peserta penyuluhan hukum tersebut. Buku saku tersebut berisi ketentuan-ketentuan mengenai hukum perkawinan termasuk di dalamnya ketentuan hukum yang mengatur mengenai poligami dan nikah siri. Untuk memudahkan penyuluhan hukum tersebut dipersiapkan pula bahan berupa power point yang dapat dilihat langsung oleh peserta ketika melakukan penyuluhan hukum.

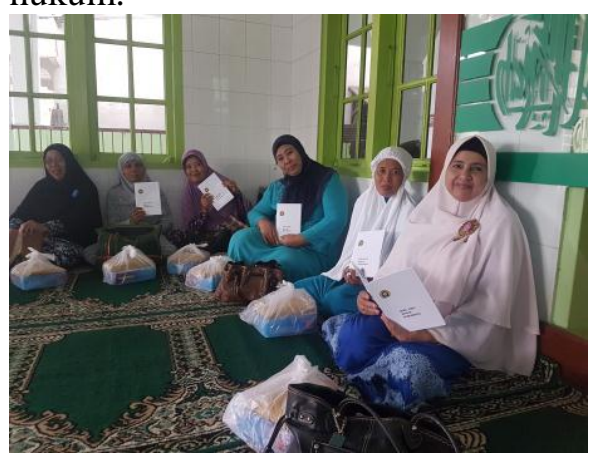

(Gambar-1. Pemberian Buku Saku kepada Peserta)

Tim Pelaksana

sebelum melaksanakan kegiatan penyuluhan hukum poligami dan nikah siri menurut undangundang perkawinan melakukan koordinasi terlebih dahulu kepada kedua mitra untuk mensosialisasikan rencana kegiatan penyuluhan hukum. Dengan sosialisasi ini dapat mengenalkan program kegiatan yang akan dilakukan dan sekaligus menentukan tanggal dilaksanakannya penyuluhan hukum tersebut.

Kegiatan ini yang diawali dengan pembukaan oleh tim penyuluh. Acara kemudian dilanjutkan dengan penyampaian materi oleh tim penyuluh. Dalam pemaparan materi peserta sangat memperhatikan penyampaian yang disampaikan oleh pemateri. Setelah penyampaian materi dilakukan sesi tanya jawab. Peserta sangat antusias dengan penyuluhan yang dilakukan karena menambah pemahaman peserta mengenai poligami dan nikah siri menurut undangundang Perkawinan. Hal ini terlihat dari banyaknya pertanyaan yang dilontarkan peserta. Atas pertanyaan-pertanyaan yang diajukan peserta tim pelatihan berupaya memberikan penjelasan secara tuntas sehingga peserta memahami dan merasa puas atas jawaban dan penjelasan yang diberikan.

Pelatihan ini kemudian ditutup dengan pembacaan doa sebagai wujud syukur kepada Allah Swt.atas kelancaran pelaksanaan kegiatan penyuluhan hukum dan diakhiri dengan foto bersama dengan peserta penyuluhan dan terbentuknya kelompok binaan yang diketuai oleh Ketua Perwiritan.

Kegiatan monitoring dan evaluasi dilakukan oleh Tim dari Lembaga Pengabdian pada Masyarakat (LPM) Universitas Sumatera Utara yang dilaksanakan pada hari Rabu Tanggal 13 September 2017 di Kelurahan Gedung Johor Kecamatan Medan Johor.

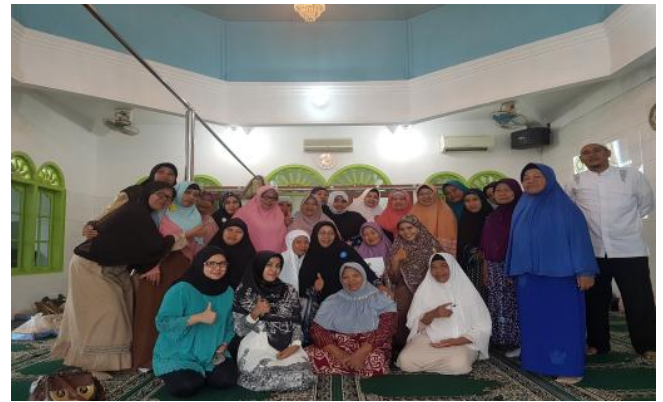

(Gambar-2. Foto Bersama Perwiritan Masjid Al-Hikmah)

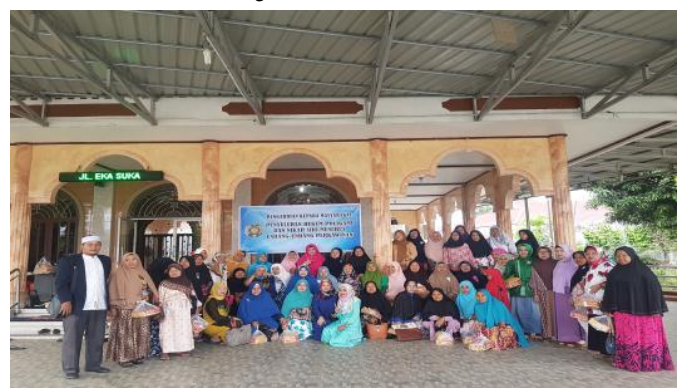

(Gambar-3. Foto Bersama Perwiritan Masjid Al-Ikhlas)

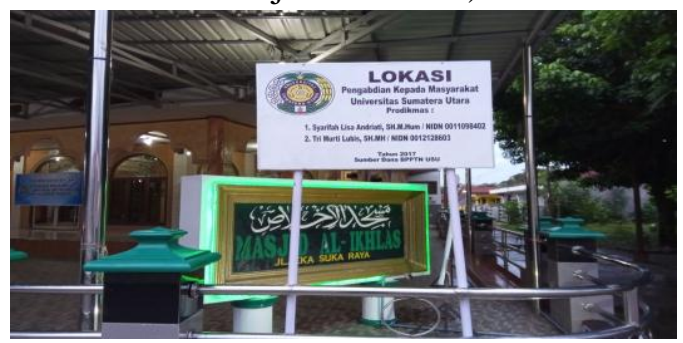

(Gambar-4. Foto Plank Pengabdian) 


\section{KESIMPULAN}

Poligami sering kurang dipahami sehingga mendapatkan tanggapan yang kurang menyenangkan dari khalayak. Meskipun demikian, disepakati bukan ajarannya yang harus disalahkan tapi lebih kepada praktik yang tidak sesuai tapi lebih sering didasarkan untuk pemenuhan nafsu. Padahal di sisi lain, poligami dapat menjadi solusi sosial apabila dilakukan secara benar. Nikah siri adalah suatu perkawinan yang dilakukan oleh orangorang Islam, memenuhi baik rukun-rukun maupun syarat-syarat perkawinan, tetapi tidak didaftarkan pada Pejabat Pencatat Nikah. Nikah siri tidak sah menurut hukum negara walaupun sah menurut hukum agama dan kepercayaannya itu. sehingga perkawinan di bawah tangan tidak mempunyai kekuatan hukum. Melalui penyuluhan ini masyarakat dapat memahami mengenai ketentuan hukum yang mengatur poligami dan nikah siri. Dan apabila terdapat kasus hukum yang berkaitan dengan poligami dan nikah siri dapat diselesaikan menurut aturan hukum yang berlaku.

\section{UCAPAN TERIMA KASIH}

Artikel ini merupakan salah satu hasil dari Program Pengabdian kepada Masyarakat yang Dibiayai oleh BPPTN Universitas Sumatera Utara Sesuai dengan Surat Perjanjian Penugasan Pelaksanaan Pengabdian kepada Masyarakat Program Mono Tahun (Dosen Muda) Tahun Anggaran2017Nomor:3224/UN5.2.3.2.1/P PM/2017, Tanggal 24 Juni 2017. Oleh karena itu, diucapkan terima kasih kepada Rektor Universitas Sumatera Utara atas dukungan dana dan fasilitas yang diberikan. Terima kasih juga kepada Mitra pada kegiatan pengabdian ini.

\section{RE6. REFERENSI}

Adillah, Siti Ummu, "Analisis Hukum Terhadap Faktor-Faktor Yang Melatarbelakangi Terjadinya Nikah Siri Dan Dampaknya Terhadap Perempuan (Istri) Dan Anak-Anak", diakses dihttp://dinamikahukum.fh.unsoed.ac.id pada tanggal 15 Mei 2017.

Afandi,Ali, Hukum Keluarga Menurut Kitab Undang-Undang Hukum Perdata (Burgerlijk Wetboek), Yayasan Gadjah Mada, Yogyakarta, tanpa tahun.

Hidayah, Khoirul, "Dualisme Hukum Perkawinan di Indonesia (Analisis Sosiologi Hukum Terhadap Praktik Nikah Siri)", Jurnal Perspektif Hukum Vol. 8 (1) Mei 2008 Universitas Hang Tuah Surabaya.

Irfan, M.Nurul, "Kriminalisasi Poligami dan Nikah Siri", Jurnal Al-'Adalah Vol 10, No 2 (2011): Volume X, No. 2, Juli 2011.

Kamello, Tan, Syarifah Lisa Andriati, Hukum Perdata: Hukum Orang dan Keluarga, USU Press, Medan, 2015.

Maloko, M.Thahir, "Nikah Siri dalam Perspektif Hukum Islam",2014, journal.uin-alauddin.ac.id diakses pada tanggal 15 Mei 2017.

Syahrani, Riduan, Perkawinan \& Perceraian bagi Pegawai Negeri Sipil, Media Sarana Press, Jakarta, 1986.

Widiastuti, "Beberapa Faktor Penyebab Pasangan Suami Isteri Melakukan Pernikahan di Bawah Tangan", Jurnal Eksplorasi Vol. XX (1) tahun 2008, LPPM Slamet Riyadi, hlm. 78-89. 